\title{
Expression and Stability of a Recombinant Plasmid in Zymomonas mobilis and Escherichia coli
}

\author{
By AMALIA S. AFENDRA AND CONSTANTIN DRAINAS* \\ Biochemistry Laboratory, Division of Organic Chemistry and Biochemistry, Department of \\ Chemistry, University of Ioannina, Ioannina 45332, Greece
}

(Received 16 May 1986; revised 12 August 1986)

\begin{abstract}
A recombinant plasmid was constructed by ligating EcoRI digests of the plasmid cloning vector pBR325 and pZMO2, one of the natural plasmids of Zymomonas mobilis ATCC 10988. This vector, named pDS212 (total size $7.9 \mathrm{~kb}$ ), which was able to transform Escherichia coli efficiently, was also transferred to $Z$. mobilis hosts by mobilization during conjugation using the helper plasmid pRK2013. pDS212 was inherited stably in both E. coli and Z. mobilis hosts and could be recovered intact from them. Markers of pBR325 and pRK2013 were also transferred in $Z$. mobilis but at very low frequencies. Neither pBR325 nor pRK2013 could be recovered intact from the Z. mobilis hosts. It is proposed that expression and stability of pDS212 in Z. mobilis is due to the origin of replication of pZMO2 that it carries, and that it may be used for developing a gene transfer system in $Z$. mobilis.
\end{abstract}

\section{INTRODUCTION}

Recent studies have shown that the Gram-negative anaerobic bacterium Zymomonas mobilis is a potential ethanol-producing micro-organism which has a number of advantages in ethanol fermentations compared to traditional yeasts (Rogers et al., 1984; Bringer et al., 1984; Doelle \& Greenfield, $1985 a, b$ ). However, the use of $Z$. mobilis in industrial ethanol fermentations is limited, because it can efficiently ferment only glucose and fructose (Swings \& De Ley, 1977). Sucrose may also be fermented but with a lower yield of ethanol, because of the formation of sorbitol and levan (Viikari, 1984a, b; Viikari \& Linko, 1986).

In spite of the considerable amount of information on the kinetics and biochemistry of $Z$. mobilis ethanol fermentations, very little is known about the genetics of the organism. Skotnicki et al. (1980) first reported transfer of R-plasmids to $Z$. mobilis by inter-species conjugation. This system was used successfully by Carey et al. (1983) to transfer and express a lactose transposon in $Z$. mobilis. Transformation of $Z$. mobilis by an in vitro cointegrate of a $Z$. mobilis natural plasmid with an Escherichia coli plasmid (total size $28 \mathrm{~kb}$ ) has also been reported (Browne et al., 1984). However, there are certain obstacles to the utilization of these plasmids as cloning vectors for $Z$. mobilis, such as their large size and unknown stability within the host cells. Plasmid molecules have been detected in various $Z$. mobilis strains (Dally et al., 1982; Tonomura et al., 1982; Drainas et al., 1983). These molecules may be used in whole or in part for the construction of suitable cloning vectors. Such a potential vector was constructed by ligating the plasmid pZMO2 of Z. mobilis ATCC 10988 (Drainas et al., 1983) in the EcoRI restriction site of the plasmid vector pBR325. In the present report the transfer, expression and stability of the above recombinant plasmid in $Z$. mobilis are described. It is proposed that this plasmid may be used as a suitable shuttle cloning vector for the development of a high-efficiency gene-transfer system in Z. mobilis.

\section{METHODS}

Growth of cultures. E. coli strains were grown in Luria media as described by Maniatis et al. (1982). Z. mobilis strains were grown in a complete liquid medium (Zymomonas broth) containing (w/v) $0 \cdot 1 \% \mathrm{KH}_{2} \mathrm{PO}_{4}, 0 \cdot 1 \%$ 


\section{Table 1. Bacterial strains and plasmids}

\begin{tabular}{|c|c|c|c|c|c|}
\hline Species & Strain & Plasmid & Plasmid marker & Source* & Reference \\
\hline \multirow[t]{6}{*}{ E. coli } & RR1 & - & - & J.R.K. & Bolivar et al. ((1977) \\
\hline & RR1 & pBR325 & $A p^{R} T c^{R} C m^{R}$ & J.R.K. & Bolivar (1979) \\
\hline & RR1 & $\mathrm{pDS} 212$ & $A p^{R} T c^{R}$ & - & Present report \\
\hline & HB101 & pRK2013 & $\mathrm{Km}^{\mathrm{R}} \mathrm{tra}^{+}$ & K. L. & Friedman et al. (1982) \\
\hline & RR1 & pRK2013 + pBR325 & $\mathrm{Km}^{\mathrm{R}} \mathrm{Ap}^{\mathrm{R}} \mathrm{Cm}^{\mathrm{R}} \mathrm{Tc}^{\mathrm{R}} \mathrm{tra}^{+}$ & - & Present report \\
\hline & RR1 & pRK2013 + pDS 212 & $\mathrm{Km}^{\mathrm{R}} \mathrm{Ap}^{\mathrm{R}} \mathrm{Tc}^{\mathrm{R}} \operatorname{tra}^{+}$ & - & Present report \\
\hline \multirow[t]{5}{*}{ Z. mobilis } & ATCC 10988 & pZMO1,2,3,4,5,6 & $\mathrm{ND}$ & W. M.L. & Drainas et al.(1983) \\
\hline & CU1 & $\mathrm{pZMO} 1,2,3,5,6$ & ND & - & Drainas et al. (1984) \\
\hline & CU1-Rif 2 & pZMO1,2,3,5,6 & ND & - & Present report \\
\hline & CP4 & pRUT41 & $\mathrm{Gm}^{\mathrm{R}} \mathrm{Km}^{\mathrm{R}} \mathrm{Str}^{\mathrm{R}}$ & W.M.L. & Walia et al. (1984) \\
\hline & NCIB 11163 & ND & ND & NCIB & 一 \\
\hline
\end{tabular}

ND, Not defined.

* J. R. K., Dr J. R. Kinghorn, University of St Andrews, UK; W. M. L., Dr W. M. Ledingham, University of St Andrews, UK; K.L., Dr K. Lindstrom, University of Helsinki, Finland; NCIB, National Collection of Industrial Bacteria, Aberdeen, UK.

$\left(\mathrm{NH}_{4}\right)_{2} \mathrm{SO}_{4}, 0.05 \% \mathrm{MgSO}_{4}, 0.5 \%$ yeast extract (Oxoid) and $2 \%$ glucose. Liquid cultures were incubated at $30^{\circ} \mathrm{C}$ without agitation. For solid media $2 \%(\mathrm{w} / \mathrm{v})$ agar (Serva) was added (Zymomonas agar). Kanamycin $\left(100 \mu \mathrm{g} \mathrm{ml} \mathrm{m}^{-1}\right)$, rifampicin $\left(10 \mu \mathrm{g} \mathrm{ml}^{-1}\right)$ or tetracycline $\left(40 \mu \mathrm{g} \mathrm{ml}^{-1}\right)$ were added to liquid or solid media as specified in the text. All $Z$. mobilis strains tested were sensitive on media containing over $50 \mu \mathrm{g} \mathrm{kanamycin} \mathrm{ml}^{-1}, 5 \mu \mathrm{g}$ rifampicin ml $\mathrm{m}^{-1}$ or $10 \mu \mathrm{g}$ tetracycline $\mathrm{ml}^{-1}$, and resistant on $100 \mu \mathrm{g}$ ampicillin $\mathrm{ml}^{-1}$.

Strains and plasmids. These are summarized in Table 1. E. coli RR1 derivatives containing both pBR 325 and pRK2013 [RR1(pRK2013 + pBR325)] or pDS212 and pRK2013 [RR1(pRK2013 + pDS212)] were constructed by conjugation. pRK 2013 is a large recombinant plasmid containing the $\mathrm{Tra}^{+}$functions of the conjugative plasmid RK2 and a gene marker coding for resistance to kanamycin (Friedman et al., 1982). Z. mobilis CU1-Rif2 (resistant to $10 \mu \mathrm{g}$ rifampicin $\mathrm{ml}^{-1}$ ) was isolated from CUl after acridine orange treatment. For this purpose $10^{8}$ cells from a late-exponential phase culture were inoculated into $10 \mathrm{ml} Z_{y}$ momonas broth containing $100 \mu \mathrm{g}$ acridine orange $\mathrm{ml}^{-1}$, and the suspension was incubated at $30^{\circ} \mathrm{C}$ for $10 \mathrm{~h}$. Rifampicin-resistant colonies were isolated after direct plating on Zymomonas agar containing $10 \mu \mathrm{g}$ rifampicin $\mathrm{ml}^{-1}$

Chemicals. Agarose, sodium dodecyl sulphate, caesium chloride, restriction endonucleases and T4 DNA ligase were from Bethesda Research Laboratories. DNA from phage P22 was kindly provided by Dr Marc Orbach (Stanford University, Calif., USA). Antibiotics were from Sigma. All other chemicals were from Serva.

Isolation and analysis of plasmids. Mini-screen tests for plasmid detection were as described by Drainas et al. (1984). Plasmids from E. coli strains were extracted and purified by $\mathrm{CsCl}$ density gradient ultracentrifugation as described by Maniatis et al. (1982). Plasmid DNA was analysed by horizontal agarose gel electrophoresis as described by Meyers et al. (1976).

Recombinant DNA procedures. Restriction digestions and ligations were done by standard methods (Maniatis $e t$ al., 1982). Plasmid pBR325 (Bolivar, 1979) was used as the cloning vector. Recombinant plasmids were isolated by direct transformation of $E$. coli RRI as described by Cohen et al. (1972).

Conjugation. Filter matings on Sartorius nitrocellulose filters $(0.45 \mu \mathrm{m}$ pore size, $25 \mathrm{~mm}$ diameter) were done by standard methods with minor modifications (Skotnicki et al., 1980). Samples of late-exponential cultures of donor and recipient strains were added to the filter at a donor : recipient ratio of $2: 1$. The filter was then placed on the surface of a solid medium plate and incubated at 30 or $37^{\circ} \mathrm{C}$ (using Z. mobilis or E. coli as recipient, respectively) for $5 \mathrm{~h}$. The cells were resuspended in liquid medium and plated on selective media for the isolation of transconjugants. E. coli RR1 transconjugants carrying both pRK2013 and pBR325 were isolated on Luria agar containing tetracycline and kanamycin $\left(20 \mu \mathrm{g} \mathrm{ml}^{-1}\right.$ each) by mating HB101(pRK2013) (donor) with RR1(pBR325) (recipient). E. coli RR1 transconjugants carrying both pRK2013 and pDS212 were isolated as above using RR1(pDS212) as the recipient.

Plasmid stability. This was estimated by measuring the stable inheritance of the antibiotic resistance plasmid markers. The percentage of $\mathrm{Tc}^{\mathrm{R}}$ (for Z, mobilis) or $\mathrm{Tc}^{\mathrm{R}}$ and $\mathrm{Ap}^{\mathrm{R}}$ (for E. coli) colonies per cell division on nonselective conditions (agar medium without antibiotic) was determined (Kieser et al., 1982).

\section{RESULTS AND DISCUSSION}

\section{Construction and restriction map of the recombinant plasmid pDS212}

We have previously shown that the natural plasmid pZMO2 of Z. mobilis ATCC 10988 (1.9 kb: Drainas et al., 1983) contains single sites for the restriction endonucleases EcoRI and 


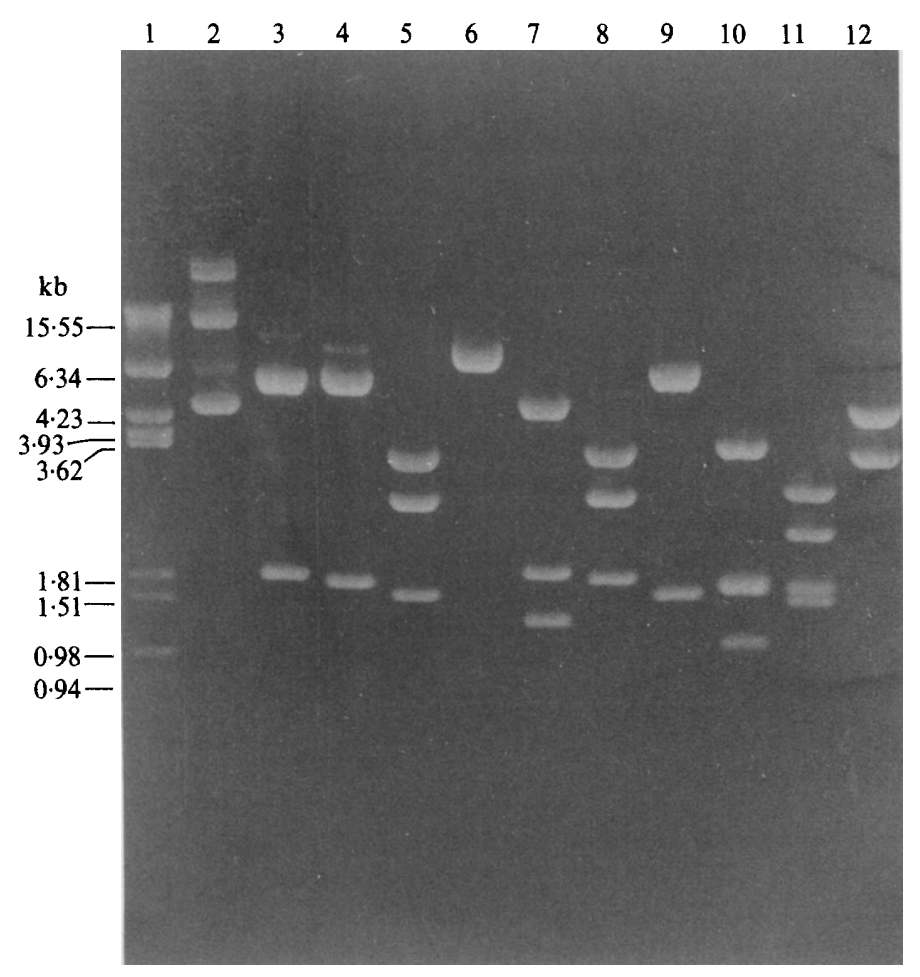

Fig. 1. Agarose gel electrophoresis of restriction fragments of pDS212. Lanes: (1) P22 DNA digested with HindIII ; (2) pDS212 not digested (front band, ccc; back bands, oc); (3-12) pDS212 digested with restriction endonucleases: (3) EcoRI, (4) EcoRV, (5) PvuII, (6) HindIII, BamHI, or PstI (linearized form), (7) EcoRI + HindIII, (8) PstI + EcoRV, (9) EcoRV + HindIII, (10) PvuII + PstI, (11) PvuII + HindIII, (12) HincII.

$E c o$ RV and two sites for PvuII (A. Scordaki \& C. Drainas, unpublished results). Therefore, a ligate of pZMO2 and pBR325, linearized by EcoRI digestions, was used to transform $E$. coli RR1. Recombinant transformants were selected for resistance to ampicillin and tetracycline, and for sensitivity to chloramphenicol. Plasmids from three recombinant transformants were isolated and purified by $\mathrm{CsCl}$ density gradient ultracentrifugation. Linear fragments produced by single and double digestions with various endonucleases were analysed by agarose gel electrophoresis (Fig. 1). The restriction maps of all the recombinant plasmids paralleled those of the parental plasmid molecules (Fig. 2). All the recombinant plasmids had a total size equivalent to $5.98+1.9 \mathrm{~kb}$. One of these, named pDS212, was tested for expression and stability in $Z$. mobilis and E. coli.

Stability of pDS212 in E. coli

The recombinant plasmid pDS212 transformed E. coli RR1 at frequencies similar to pBR325 $\left(1 \times 10^{5}\right.$ and $3.3 \times 10^{5}$ transformants per $\mu \mathrm{g}$ DNA respectively). Six isolates picked randomly from among these transformants were tested for plasmid stability. All maintained both the gene markers of pDS 212 at a frequency of $98 \%$ after 60 cell divisions under non-selective conditions (Table 2).

\section{Transfer, expression and stability of pDS212 in Z. mobilis}

Efforts were made to transform the Z. mobilis strains NCIB 11163, CP4 and CU1-Rif2 with either pBR325 or pDS212. Methods previously described to be successful for Z. mobilis (Browne 


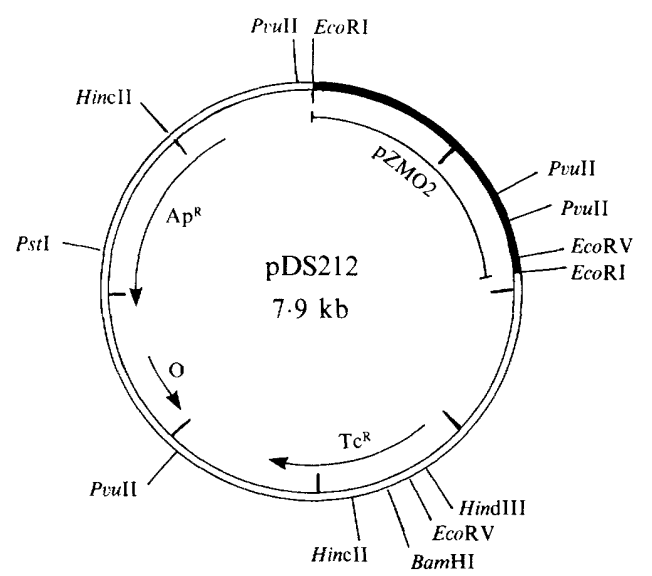

Fig. 2. Restriction map of pDS212 (one division $\simeq 1 \mathrm{~kb}$ ).

Table 2. Stability of pDS212 in E. coli and Z. mobilis

\begin{tabular}{lcccccccc} 
& & \multicolumn{7}{c}{ No. of cell divisions: } \\
\cline { 3 - 8 } & & & & Plasmid stability* \\
Strain & Plasmid & 0 & 10 & 20 & 30 & 40 & 50 & 60 \\
RR1 & pBR325 & 100 & 100 & 100 & 100 & 100 & 100 & 100 \\
RR1 & pDS212 & 100 & 100 & 100 & 100 & 100 & 99 & 98 \\
CU1-Rif2 & pDS212 & 100 & 100 & 99 & 98 & 97 & 95 & 93
\end{tabular}

* Estimated as the percentage of colonies expressing the plasmid markers after growth on non-selective conditions (500 colonies were tested).

et al., 1984) were used without success. Tc ${ }^{\mathrm{R}}$ colonies were obtained at low frequencies $\left(\sim 3 \times 10^{-6}\right.$ transformants per $\mu \mathrm{g}$ DNA), but pDS212 was not recovered either on plasmid mini-screens or by back-transformation in $E$. coli. It was therefore concluded that resistance to tetracycline could be due to the spontaneous mutation frequency, under the conditions of the experiment. Conjugative plasmids like pRK2013 (Friedman et al., 1982) are known to mobilize other nonconjugative plasmids during conjugation. Although pDS212 is not a conjugative plasmid, its transfer in Z. mobilis was accomplished by this method using CU1-Rif2 as recipient and E. coli RR1(pRK2013 + pDS212) as donor. The transfer frequency was approximately $10^{-4}$ transconjugants per recipient (Table 3). Selection of transconjugants was made after $7 \mathrm{~d}$ incubation at $30^{\circ} \mathrm{C}$ on $Z$. mobilis agar medium containing $40 \mu \mathrm{g}$ tetracycline $\mathrm{ml}^{-1}$ (Table 3). Liquid growth tests showed that these transconjugants could grow in the presence of up to $60 \mu \mathrm{g}$ tetracycline $\mathrm{ml}^{-1}$.

E. coli RR1(pRK2013 + pBR325) donors were used to test possible transfer and expression of the vector $\mathrm{pBR} 325$ in CU1-Rif 2 recipients. $T \mathrm{c}^{\mathrm{R}}$ putative transconjugants were again obtained but at very low frequency (Table 3 ). These transconjugants appeared $2 \mathrm{~d}$ later on the selective medium than did those described above, and they were not able to grow in the presence of over $20 \mu \mathrm{g}$ tetracycline $\mathrm{ml}^{-1}$ in liquid medium, an indication that the transferred marker was present

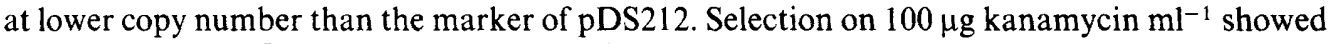
transfer of the $\mathrm{Km}^{\mathrm{R}}$ marker of the conjugative plasmid pRK2013 at low frequency when either donor was used (Table 3). Transconjugants on selective media containing both tetracycline and kanamycin were not obtained.

Six $\mathrm{Tc}^{\mathrm{R}}$ and $\mathrm{Km}^{\mathrm{R}}$ isolates were picked at random among the $Z$. mobilis transconjugants from each of the above conjugations and were tested by the mini-screen method for occurrence of 


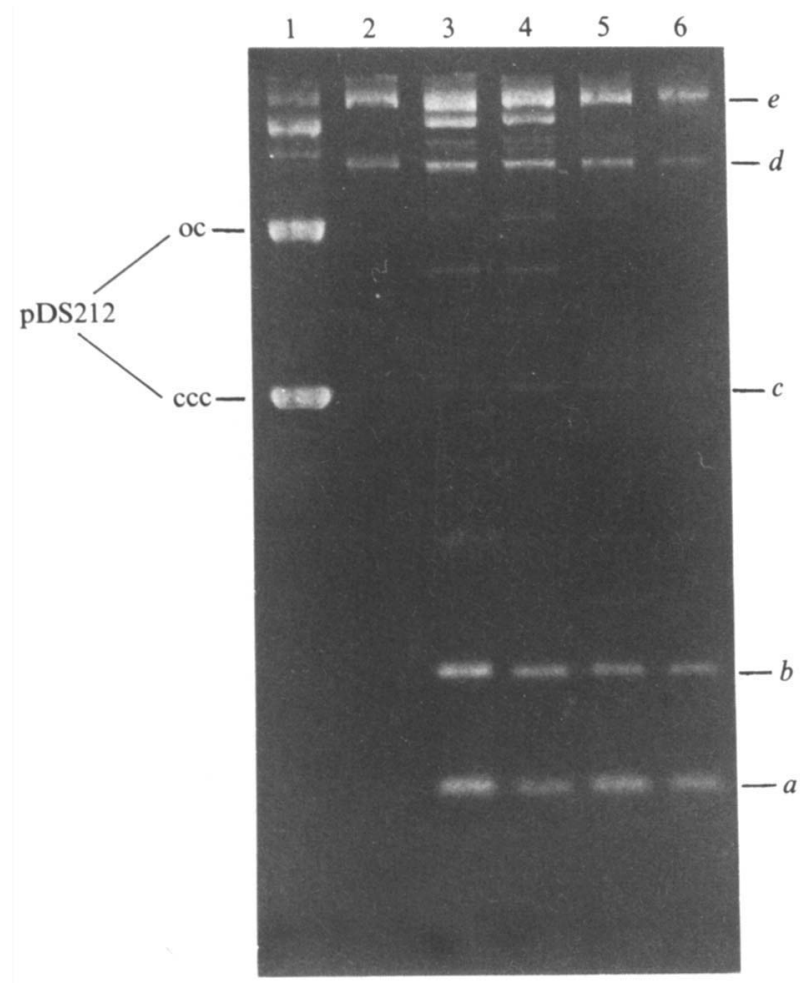

Fig. 3. Mini-screen test for plasmids of Z. mobilis transconjugants. Lanes: (1) RR1(pDS212), (2) HB10l (pRK2013), (3) tcj 1, (4) tcj 2, (5) tcj 3, (6) CUl-Rif 2. tcj, Z. mobilis transconjugants containing pDS212 (tcj 4, 5, 6 were similar to tcj 1,2, 3 and are omitted for clarity); $a, b, c, d, e, Z$. mobilis natural plasmids.

Table 3. Mobilization of pDS212 in CUI-Rif 2 by conjugation

\begin{tabular}{cl} 
No. & \multicolumn{1}{c}{ Donor $\left(2 \times 10^{8}\right)$} \\
1 & RR1(pRK2013 + pDS212) \\
2 & RR1(pRK2013 + pBR325) \\
3 & RR1(pBR325) \\
4 & RR1(pDS212) \\
5 & RR1(pRK2013 + pDS212) \\
6 & RR1(pRK2013 + pBR325) \\
7 & -
\end{tabular}

\begin{tabular}{ccc} 
Recipient & \multicolumn{2}{c}{$\begin{array}{c}\text { Frequency of } \\
\text { transconjugants* }\end{array}$} \\
\cline { 2 - 3 }$\left(1 \times 10^{8}\right)$ & Rif + Tc & Rif + Km \\
CU1-Rif2 & $1 \times 10^{-4}$ & $3 \times 10^{-7}$ \\
CU1-Rif2 & $3.5 \times 10^{-7}$ & $3.5 \times 10^{-7}$ \\
CU1-Rif2 & $<10^{-8}$ & $<10^{-8}$ \\
CU1-Rif2 & $<10^{-8}$ & $<10^{-8}$ \\
- & $<10^{-8}$ & $<10^{-8}$ \\
CU1-Rif2 & $<10^{-8}$ & $<10^{-8}$ \\
& $<10^{-8}$ & $<10^{-8}$
\end{tabular}

* The values are the means of six repeats. The selective conditions were either $10 \mu \mathrm{g} \mathrm{Rif} \mathrm{ml}^{-1}+40 \mu \mathrm{g} \mathrm{Tc} \mathrm{ml} \mathrm{m}^{-1}$ or $10 \mu \mathrm{g}$ Rif $\mathrm{ml}^{-1}+100 \mu \mathrm{g} \mathrm{Km} \mathrm{ml}{ }^{-1}$,

transferred plasmid molecules. The plasmid profiles obtained by agarose gel electrophoresis of extracts of $Z$. mobilis transconjugants from conjugation no. 1 (where pDS212 was the mobilized plasmid: Table 3) revealed a band corresponding to the open circle of plasmid pDS212 (Fig. 3). This band was absent from the recipient CU1-Rif 2 . It would be expected that the native plasmid pZMO2 should not be maintained together with pDS212, because they share a common origin of replication. This cannot be been in Fig. 3, because it has been proved that plasmid pZMO2 co- 


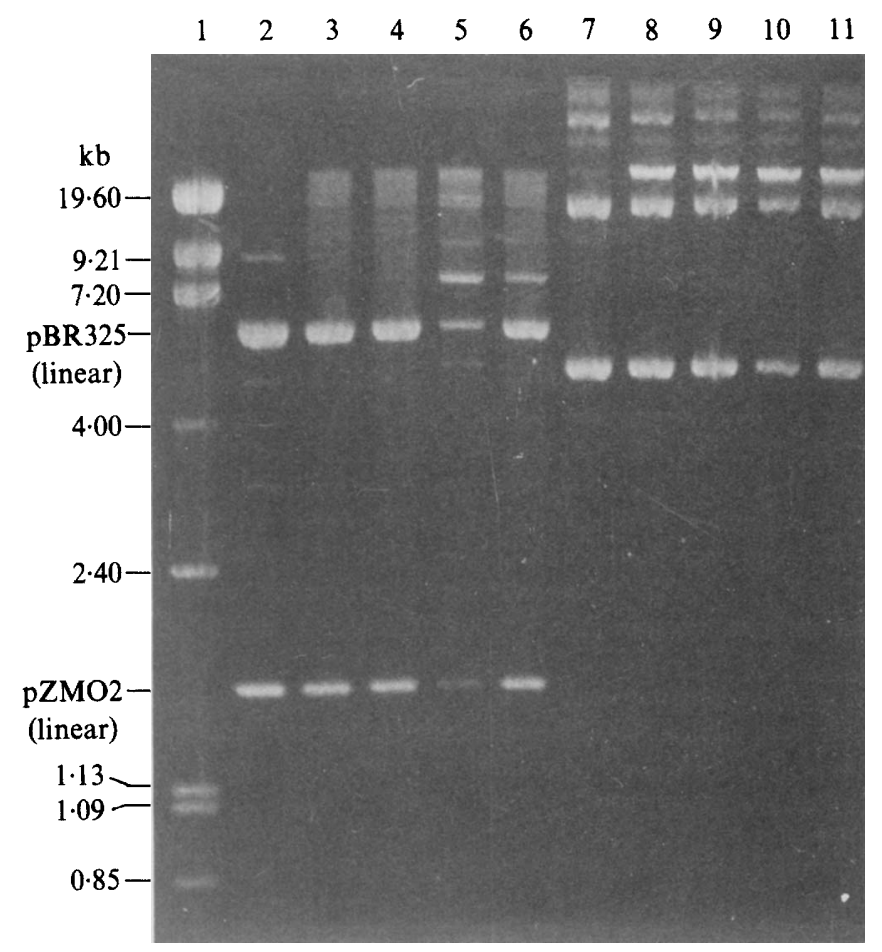

Fig. 4. Structural analysis of pDS212 isolated from $Z$. mobilis hosts and transferred into $E$. coli. Lanes: (1) P22 DNA digested with EcoRI; (2) pDS212 purified on a $\mathrm{CsCl}$ density gradient digested with EcoRI ; (3) mini-screen plasmid extract of RR1(pDS212) digested with EcoRI ; (4), (5), (6) mini-screen plasmid extracts of RR1 transformed by extracts of tcj 1, 2 and 3, respectively, digested with EcoRI; (7)-(11) as for (2)-(6), respectively, but not digested.

migrates with pZMOl on agarose gels (A. Scordaki \& C. Drainas, unpublished results). Therefore, band $(a)$ in Fig. 3 should represent pZMO1. The plasmid profiles of the $\mathrm{Km}^{\mathrm{R}}$ and the $\mathrm{Tc}^{\mathrm{R}}$ transconjugants from conjugation no. 2 (where pBR325 was the mobilized plasmid: Table 3 ) were identical to the profile of CU1-Rif2 and for clarity are omitted from Fig. 3.

The plasmid extracts of the transconjugants from both conjugations were used to transform $E$. coli RR1. Extracts of transconjugants from conjugation no. 1 transformed RR1 for both markers of pDS212 (Table 4). Plasmid profiles of extracts from these transformants showed the bands of pDS212. A restriction digest of the extracts with EcoRI recovered the linear fragments corresponding to pBR325 and pDS212 (Fig. 4). Three randomly selected Z. mobilis CU1-Rif2 transconjugants carrying pDS212 were grown on non-selective liquid medium to test plasmid stability. The $\mathrm{Tc}^{\mathrm{R}}$ marker was maintained at a frequency of $93 \%$ after 60 cell divisions under non-selective conditions (Table 2). Three $\mathrm{Tc}^{\mathrm{R}}$ transconjugants isolated at random after 60 cell divisions under selective or non-selective conditions respectively showed the same plasmid stability and integrity for pDS212 as above (results not shown). These results strongly indicate that pDS212 was transferred and expressed stably in $Z$. mobilis cells as an intact plasmid molecule and that it remained as such after many rounds of replication.

Plasmid extracts of $\mathrm{Tc}^{\mathrm{R}}$ transconjugants from conjugation no. 2 (Table 3 ) transformed RR1 for $T c^{R}$ at a frequency 1000 -fold lower than the above (Table 4). None of these transformants carried all the markers of pBR325. Restriction analysis of plasmid DNA isolated from both Aps and $\mathrm{Cm}^{\mathrm{s}}$ transformants had a different pattern from either $\mathrm{pBR} 325$ or pDS212. These results indicate that pBR325 undergoes genetic rearrangement within the $Z$. mobilis hosts. This rearrangement did not lead to spontaneous in vivo formation of a recombinant plasmid molecule 
Table 4. Transformation of E. coli RRI with plasmid extracts from Z. mobilis transconjugants

\begin{tabular}{|c|c|c|c|c|}
\hline \multirow{2}{*}{$\begin{array}{l}\text { Transconjugant } \\
\text { plasmid extract* }\end{array}$} & \multicolumn{4}{|c|}{ Frequency of transformation $\dagger$} \\
\hline & Ap & $\mathrm{Tc}$ & $\mathrm{Cm}$ & $\mathrm{Km}$ \\
\hline $\operatorname{tcj} 1$ & $3.8 \times 10^{-3}$ & $3.8 \times 10^{-3}$ & - & - \\
\hline $\operatorname{tcj} 2$ & $3.5 \times 10^{-3}$ & $3.5 \times 10^{-3}$ & - & _- \\
\hline $\operatorname{tcj} 3$ & $2.8 \times 10^{-3}$ & $2.8 \times 10^{-3}$ & - & - \\
\hline $\operatorname{tcj} 4$ & $2.5 \times 10^{-3}$ & $2.5 \times 10^{-3}$ & - & - \\
\hline $\operatorname{tcj} 5$ & $4.9 \times 10^{-3}$ & $4.9 \times 10^{-3}$ & - & - \\
\hline $\operatorname{tcj} 6$ & $4.3 \times 10^{-3}$ & $4.3 \times 10^{-3}$ & - & - \\
\hline tcj 11 & - & - & - & $2.5 \times 10^{-5}$ \\
\hline tcj 12 & - & - & - & $2.1 \times 10^{-5}$ \\
\hline tcj 13 & - & - & - & $2.3 \times 10^{-5}$ \\
\hline tcj 27 & $4 \cdot 1 \times 10^{-6}$ & $4 \cdot 1 \times 10^{-6}$ & -- & - \\
\hline tcj 28 & - & $4.7 \times 10^{-6}$ & $4.7 \times 10^{-6}$ & - \\
\hline tcj 29 & - & $3.8 \times 10^{-6}$ & $3.8 \times 10^{-6}$ & - \\
\hline
\end{tabular}

${ }^{*} \operatorname{tcj}$ 1-6: CU1-Rif2 $\mathrm{Tc}^{\mathrm{R}}$ transconjugants from mobilization of pDS212; tcj 11-13: CU1-Rif $2 \mathrm{Km}^{\mathrm{R}}$ transconjugants from mobilization of pDS212 and pBR325; tcj 27-29: CU1-Rif $2 \mathrm{Tc}^{\mathrm{R}}$ transconjugants from mobilization of $\mathrm{pBR} 325$.

$\dagger$ No. of transformants per recipient $\left(\sim 10^{8}\right.$ recipient $E$. coli RR I cells were used per transformation). The frequency of spontaneous resistance was $<1 \times 10^{-8}$ in all cases.

equivalent to $\mathrm{pDS} 212$. Plasmid extracts of $\mathrm{Km}^{\mathrm{R}}$ Z. mobilis transconjugants were also able to transform RR1 for $\mathrm{Km}^{\mathrm{R}}$, but again at a low frequency (Table 4). Restriction analysis of the transforming plasmids gave a different pattern from the restriction of pRK2013 and it was again concluded that the helper plasmid also undergoes genetic rearrangement within the $Z$. mobilis hosts. Study of the molecular events following these genetic rearrangements is in progress.

\section{General conclusions}

The recombinant plasmid pDS212 derived from the ligation of pBR325 and pZMO2, which transformed $E$. coli efficiently, was also transferred, replicated and expressed stably in $Z$. mobilis. In contrast, the parental plasmid vector pBR325 and the helper conjugative plasmid pRK2013 were transferred to $Z$. mobilis hosts at very low frequencies and failed to express stably in the same hosts. The above evidence supports the theory that the expression and stability of pDS212 in Z. mobilis and E. coli is due to the origins of replication for both organisms that it carries. The recombinant plasmid pDS212 has a number of advantages as a potential cloning vector for developing a gene transfer system in $Z$. mobilis. These may be summarized as follows: (1) it has a small size $(7.9 \mathrm{~kb})$; (2) it carries two convenient gene markers with single restriction sites within them, suitable for cloning DNA fragments; (3) it can replicate and express stably in Z. mobilis and E. coli. The failure to transform Z. mobilis with pDS212 may be due to DNA uptake limitations or to a possible restriction system. Research on this problem is in progress.

Two reports describing cloning vectors for $Z$. mobilis appeared while this manuscript was being reviewed. In the first, cloning vectors were constructed by ligation of a $3.9 \mathrm{~kb}$ natural plasmid of $Z$. mobilis and plasmid pACYC184 (Tonomura et al., 1986). All the constructed recombinant vectors had low stability in the $Z$. mobilis hosts $(38-77 \%$ after about six cell divisions under non-selective conditions) and only one available marker $\left(\mathrm{Tc}^{\mathrm{R}}\right.$ or $\left.\mathrm{Cm}^{\mathrm{R}}\right)$ for cloning foreign DNA. In the second, a vector carrying a deletion derivative of $\mathrm{pBR} 327$, the lactose permease gene and a functional $\beta$-galactosidase fragment was proved suitable for isolating Z. mobilis promoters (Byun et al., 1986). However, the vector has instability problems and apparently is larger than pDS212. In conclusion, for the reasons listed above, we propose that pDS212 is more advantageous for cloning in Z. mobilis. In particular, a recombination of pDS21 2 with Z. mobilis promoters, as speculated by Byun et al. (1986), may produce a stable and high-expression vector for developing an efficient gene transfer system in $Z$. mobilis. 
We are grateful to Dr M. A. Typas and Dr J. R. Kinghorn for critical reading of the manuscript, to Dr W. M. Ledingham for providing the Z. mobilis strains ATCC 10988 and CP4, to Dr K. Lingstrom for providing HB101(pRK2013) and to Dr Marc Orbach for providing P22 DNA. We also wish to acknowledge the contribution of A. Scordaki to the construction of pDS212.

This work was supported financially by the Greek Government (Ministry of Industry, Energy and Natural Resources, PAET 1984) and by the Commission of the European Communities (Biomolecular Engineering Programme, Contract no. GBI-3-098-GR).

\section{REFERENCES}

Bolivar, F. (1979). Molecular cloning vehicles derived from the ColE1 type plasmid pMB1. Life Sciences 25, 807-818.

Bolivar, F., Rodriguez, R. L., Greene, P. J., Betlach, M. C., Heyneker, H. L., Boyer, H. W., Cross, J. H. \& FalKow, S. (1977). Construction and characterization of new cloning vehicles. II. A multipurpose cloning system. Gene 2, 95-113.

Bringer, S., SAHM, H. \& SWyzen, W. (1984). Ethanol production by Zymomonas mobilis and its application on an industrial scale. Biotechnology and Bioengineering Symposium 14, 311-319.

Browne, G. M., Skotnicki, M. L., Goodman, A. E. \& ROGERS, P. L. (1984). Transformation of Zymomonas mobilis by a hybrid plasmid. Plasmid 12, 211-214.

BYun, M. O.-K., KAPER, J. B. \& IngRam, L. O. (1986). Construction of a new vector for the expression of foreign genes in Zymononas mobilis. Journal of Industrial Microbiology 1, 9-15.

Carey, V. C., Walia, S. K. \& Ingram, L. O. (1983). Expression of a lactose transposon (Tn95I) in Zymomonas mobilis. Applied and Environmental Microbiology 46, 1163-1168.

Cohen, S. N., Chang, A. C. Y. \& Hsu, L. (1972), Nonchromosomal antibiotic resistance in bacteria: transformation of $E$. coli by R-factor DNA. Proceedings of the National Academy of Sciences of the United States of America 69, 2110-2114.

Dally, E. L., Stokes, H. W. \& Eveleigh, D. E. (1982). A genetic comparison of strains of Zymomonas mobilis by analysis of plasmid DNA. Biotechnology Letters 4, 91-96.

Doelle, H. W. \& Greenfield, P. F. (1985a). The production of ethanol from sucrose using Zymomonas mobilis. Applied Microbiology and Biotechnology 22, 405-410.

Doelle, H. W. \& Greenfield, P. F. (1985b). Fermentation pattern of Zymomonas mobilis at high sucrose concentrations. Applied Microbiology and Biotechnology 22, 411-415.

Drainas, C., Slater, A. A., Coggins, L., Montague, P., Costa, R. G., LedinghaM, W. M. \& KinghorN, J. R. (1983). Electron microscopic analysis of Zymomonas mobilis strain ATCC 10988 plasmid DNA. Biotechnology Letters 5, 405-408.

Drainas, C., Typas, M. A. \& Kinghorn, J. R. (1984). A derivative of Zymomonas mobilis ATCC 10988 with impaired ethanol production. Biotechnology Letters 6, 37-42.
Friedman, A. M., Long, S. R., Brown, S. E., Buikema, W. J. \& Ausubel, F. M. (1982). Construction of a broad host range cosmid vector and its use in the genetic analysis of Rhizobium mutants. Gene 18, 289-296.

Kieser, T., HoPWOOD, D. A., Wright, H. M. \& THOMPSON, C. T. (1982). pIJ101, a multicopy broadhost-range Streptomyces plasmid : functional analysis and development of DNA cloning vectors. Molecular and General Genetics 185, 223-238.

Maniatis, T., Fritsch, E. F. \& Sambrook, J. (1982). Molecular Cloning: A Laboratory Manual. Cold Spring Harbor, NY: Cold Spring Harbor Laboratory.

Meyers, J. A., Sanchez, D., Elwell, L. P. \& FaLKow, S. (1976). Simple agarose gel electrophoresis method for the identification and characterization of plasmid deoxyribonucleic acid. Journal of Bacteriology 127, 1529-1538.

Rogers, P. L., Goodman, A. E. \& Heyes, R. H. (1984). Zymomonas ethanol fermentations. Microbiological Sciences 1, 133-136.

Skotnicki, M. L., Tribe, D. E. \& Rogers, P. L. (1980). R-plasmid transfer in Zymomonas mobilis. Applied and Environmental Microbiology 40, 7-12.

Swings, J. \& DE LEY, J. (1977). The biology of Zymomonas. Bacteriological Reviews 41, 1-46.

Tonomura, K., Kurose, N., Konishi, S. \& Kawasaki, H. (1982). Occurrence of plasmids in Zymomonas mobilis. Agricultural and Biological Chemistry 46, 2851-2853.

Tonomura, K., OKamoto, T., Yasui, M. \& Yanase, $H$. (1986). Shuttle vectors for Zymomonas mobilis. Agricultural and Biological Chemistry 50, 805-808.

VIIKARI, L. (1984a). Formation of levan and sorbitol from sucrose by Zymomonas mobilis. Applied Microbiology and Biotechnology 19, 252-255.

VIIKARI, L. (1984b). Formation of sorbitol by Zymomonas mobilis. Applied Microbiology and Biotechnology 20, 118-123.

VIIKARI, L. \& LINKo, M. (1986). Rate and yield limiting factors in continuous fermentation of sucrose by Zymomonas mobilis. Biotechnology Letters 8, 139-144.

Walia, S. K., CAREY, V. C., All, B. P., III \& Ingram, L. O. (1984). Self-transmissible plasmid in Zymomonas mobilis carrying antibiotic resistance. Applied and Environmental Microbiology 47, 198-200. 